\title{
Money, power and inequality among married couples in urban Sarawak
}

\author{
Lynn $\mathrm{Wee}^{1 *}$ \\ ${ }^{1}$ Swinburne University of Technology, Sarawak Campus, Faculty of Business, Design and Arts, Jalan Simpang Tiga, 93250, \\ Kuching, Sarawak, Malaysia
}

\begin{abstract}
In accordance with United Nations' sustainable development goal in achieving gender equality and to empower all women and girls, this paper investigates gender equality and power in marital relationship. Using Resource Theory of Power as a conceptual framework, this paper examines the distribution of marital power among married couples. More specifically, this paper examines to what extent do married couples use money as a bargaining tool to negotiate for more control in two areas: (1) managing economic resources and (2) household decision making. Forty married couples from urban Sarawak were located and interviewed. Results indicate that apart from money, marital power is affected by more influential factors such as ideologies and religious teachings. Consequently, having more money does not necessarily mean having more control over the decision making as decision making in a marriage is often guided by prescribed gender roles in accordance to one's ideologies, cultural and religious teachings. Hence, gender equality in the management of economic resources and decision making within a household can only occur when an increase in women's resources is combined with changes in gender roles and ideologies.
\end{abstract}

\section{Introduction}

Power is a fundamental aspect of a marital relationship and has been defined and measured in different ways. In 1960, Blood and Wolfe examined power in the family and presented their resource theory of power which they defined power as "the potential ability of one partner to influence the other's behavior", manifested "in the ability to make decisions affecting the life of the family" (Blood \& Wolf, 1960, p.11). In accordance with resource theory, the partner who brings more socio-economic resources - such as income, education and occupational status into a marriage - will tend to make most of the marital decisions. The implication from this theory is that to gain power so as to be on par with their husbands in a marriage, women would need access to independent wages. Indeed, this was the feminist agenda during the 1960s and 1970s, where feminist scholars and writers encouraged millions of global women to enter the workforce so as to increase their self-worth, autonomy and power within their marriage. This agenda received positive responses from women around the world including Malaysian women. As Malaysia underwent rapid economic growth between 1970 and 1995, there was an increase in women's participation in the labour force - from 32.2 per cent to 44.7 per cent. In 2019 , women accounted for 55.7 per cent of the country's workforce (Department of Statistics, 2020). However, studies have indicated that even though more and more married Malaysian women are participating in the labour force, their responsibilities as the primary care giver in the family have not diminished (Noor Rahamad, 1996; R Noraini M Noor, 1999; Rahmah Ismail \& Fatimah, 1999; Roziah Omar, 2003) with many experiencing work-family conflicts when juggling their multiple roles as an employee, mother and wife (Aminah Ahmad, 1995). The findings of many studies in the United Kingdom and Unites States also indicate that men's power and privileges have been largely preserved despite women's increasing participation in the workforce (Coltrane, 2000; Pyke, 1994; Tichenor, 1999).

One of the main criticisms of resource theory is the failure to capture the cultural impact of personal ideologies on marital power. Researchers such as Demsy (1997) and others (Agarwal, 1997; Xu \& Lai, 2002) have argued that households do not appear in isolation, but are embedded in societies with different cultural practices and ideological principles, such as gender and age hierarchies, and we cannot satisfactorily understand inequality until we examine between the institution of marriage and wider structures and cultural processes. Barret (cited in Dempsy, 1997, p.124) added that the significance of ideology cannot be underestimated as it has direct influence on the oppression and maintenance of women's subordination in many societies. Feminists from varying perspectives affirm that beliefs about what is appropriate for men and women to justify and maintain sex segregation in both private and public arena - used

\footnotetext{
* Corresponding author: lwee@swinburne.edu.my
} 
by men, for example, to give credence to their leadership position and to legitimize women's supportive and subordinated role in marriage. Men further use these beliefs to justify their access to material rewards, autonomy and personal leisure. Women to a lesser extent also use them to justify men's superior position and rewards. It is this process of construction and reaffirmation of gender that in turn influences the way couples relate to each other, make decisions and the organization of domestic work in their households.

\section{Methodology}

This paper uses qualitative data which were extracted from interviews conducted of 40 married couples based in urban Sarawak, Malaysia. The participants were city dwellers living in Kuching and Miri. Sarawak is a multicultural society which consists of people from different ethnic backgrounds with different religious beliefs and cultural values. For the ease of classification, the participants were divided into Chinese and Non-Chinese. The Chinese comprises of all Chinese couples and Non-Chinese comprises of couples such as Malays, Ibans, Bidayuhs, Orang Ulus and Melanaus.

The participants in this study were recruited through the snowballing technique through friends and acquaintances. The age of the couples ranges from 20 to more than 50 years and each couple had at least one dependent child living with them. The couples were further categorized based on their level income. In sum, the participants consisted of two income groups; high income couples (with a net monthly household income above RM3,000) and low-income couples (with a net monthly household income below RM3,000). Table 1.1 provide a summary of the categorization of participants based on household income and ethnicity. The participants were from a wide range of occupations: some professionals; a few entrepreneurs; and others in a variety of skilled and unskilled employment. The majority of them are Christians, some were Buddhists, Muslims and other religious affiliations were also represented. To protect the anonymity of the participants, all of their names have been changed.

\begin{tabular}{|c|c|c|c|c|}
\hline \multicolumn{5}{|c|}{$\begin{array}{c}\text { TABLE 1.1 } \\
\text { Number of Participants Based on Househol }\end{array}$} \\
\hline \multirow[t]{2}{*}{$\begin{array}{l}\text { Household Income } \\
\text { (Ringgit) }\end{array}$} & \multirow[t]{2}{*}{ Ethnicity } & \multirow[t]{2}{*}{ Total } & \multicolumn{2}{|c|}{ Gender } \\
\hline & & & Male & Female \\
\hline Greater than 3000 & Chinese & 28 & 13 & 15 \\
\hline \multirow[t]{2}{*}{ Less than 3000} & Chinese & 12 & 6 & 6 \\
\hline & & 40 & 19 & 21 \\
\hline \multirow{6}{*}{ Greater than 3000} & Non-Chinese & & & \\
\hline & Bidayuh & 11 & 8 & 3 \\
\hline & Iban & 2 & 1 & 1 \\
\hline & Orang Ulu & 3 & 0 & 3 \\
\hline & Malay & 5 & 2 & 3 \\
\hline & Melanau & 1 & 1 & 0 \\
\hline & & 22 & 12 & 10 \\
\hline \multirow{4}{*}{ Less than 3000} & Non-Chinese & & & \\
\hline & Bidayuh & 8 & 4 & 4 \\
\hline & Malay & 10 & 5 & 5 \\
\hline & & 18 & 9 & 9 \\
\hline \multicolumn{2}{|c|}{ Total number of participants } & 80 & 40 & 40 \\
\hline
\end{tabular}




\section{Results}

The majority of participants in my study do not associate "power" and "control" in relation to money. Many spoke of controlling money, rather than using money to control their partners in the marriage: they talked about the need to keep the flow of money under control, or controlling where the money went, with only a few participants claiming that having more money gave them more control in their households. When it comes to decision making in the households, the majority of participants do not associate money with decision making in their households. Of those that did (11 out of 70 responses), there were more females than males that acknowledge such association.

In addition, the majority of couples denied having conflicts over money issues with their spouses. Others claimed that such conflicts existed, but they were minor and trivial. Based on these findings, it is tempting to conclude that there were no significant power issues among the couples in my study and they were fairly content with their existing marital relations. Drawing such a conclusion maybe, however seriously flawed. Komter (1989) in examining marital relationship argued that a lack of conflict might be an indication of the existence of power and an unequal relationship. Shove (1993) also criticized findings from reported household conflict as being limited as the responses were merely the end result of the workings of power and neither reflected nor explained the underlying mechanisms of how power operated within marital relationships.

My study revealed that ideologies held by couples is the major determinant that influences the working and distribution of power in marital relationship such as gender roles ideology and religious teachings. Gender ideology refers to attitudes regarding the appropriate roles, rights and responsibilities of women and men in society. This ideology would in turn gives rise to what West and Zimmerman (1987) referred to as "doing gender". An example of "doing gender" from my study includes the majority of participants' regard for domestic chores such as cooking, grocery shopping, housework and taking care of children as "women's work" and thus decision making in these areas were best left to the women. Men on the other hand were seen as having an upper hand and being more knowledgeable about technical things, financial planning and investment decisions and thus they should exert more say in these matters. Examples of such legitimations include: "As a husband, I will have more say in "man's things", others like children's things are "hers", "Major issues my husband will assert more, minor issues, is me", "It depends on which area - food, cooking, domestic and children my wife will have more say; car repair and maintenance, I will have more say." Another related ideology is the male breadwinner ideology which considered men's participation in the labour market as primary and valued more than women's labour. Consequently, men were paid more than women on the grounds that they had to support their families (though in practice their wages did not always suffice). Many female participants from my study held onto this male breadwinner ideology and considered their husbands as the breadwinner of the house. Thus, when it came to decision making, the husband still had power to veto his wife's decisions.

Julie and Harry were one such couple. They had been married for 25 years and had four children. Julie was in her late 40 s and she worked as a primary school teacher. Harry was in her early 50s and a driver for a government department. Julie earned between 2,000 and 3,999 Ringgit a month and Harry earned a monthly income of 1,000 to 1,999 Ringgit. Even though Julie earned double her husband's income, she still considered her husband the breadwinner and/or head of the household and thus the main decision maker. Harry had similar feelings and said:

"In our household, we don't decide based on income. Whoever is the head of the household, and whatever he decides, you have to respect that."

Serena and Edwin are another couple where the wife earned more than her husband. Like Julie, Serena still considered her husband the male breadwinner of the family and downplayed her role in decision making. According to Serena, even when it came to personal expenditure, she still listened to her husband:

"I consider my husband as the breadwinner of the family. Even though I earn more than him, I still cling to him. Some people think I am dominant but, deep inside, I always seek his advice and if he says no, I will not."

Serena's narrative on her effort to downplay her role in decision making was affirmed by her husband in a separate interview.

While women (and men) may profess egalitarian beliefs, they may also simultaneously hold traditional beliefs. The behavior of these individuals is very often motivated by goals and notions that have more affinity with patriarchal values 
and a sense of femaleness and maleness ("doing gender") than with notions of equality between men and women. Kelly is one individual. She is a lecturer in her mid-40s, married to an accountant. When Kelly was asked if earning more meant more power in decision making in her house, her reply was:

"No, not in my house because we are not the traditional type...both my husband and I are educated and democratic so the way we run the house is democratic...50/50 in decision making...but I still manage and control the household decisions and anything outside the house, I let him do...He is very busy with his work and he is a workaholic, which I believe is what a father should be...so I try not to bother him with too many household things like paying the household bills."

Kelly spoke of democratic and equity in decision making in her household because she claimed both she and her husband were educated individuals. Therefore, unlike a "traditional" male-breadwinner household, decision making in her house would be more egalitarian. However, when she described how decision making operated in reality, she contradicted her own beliefs. For example, she claimed she was in charge in paying and managing utility bills and affairs of her children. Her husband on the other hand was in charge of mortgage, long term financial planning and investment decisions. According to her, her husband would manage "anything outside the house". In addition, she felt that her husband behaved like a father should in terms of concentrating on work and bringing in income. This also reflects her ideology of the man as breadwinner. The apparent gap between Kelly's beliefs and her behavior may be because she is more emotionally attached to her traditional beliefs than her egalitarian beliefs.

The other influential ideology is that of religious teachings. Two couples from my study that professed their strong Christian beliefs and explained how if affected the division of power in their marital relationship - one such couple was Ben and Zena who have been married for ten years. Zena is a lecturer who earned a monthly income of approximately 4,000 to 4,999 Ringgit and Ben is a computer programmer who earned more than 6,000 Ringgit a month. They had two boys aged 9 and 7 . When I asked Ben about decision making in his house, he said:

"In the Christian belief, the husband is the head of the house. The wife submits to the husband, not in a dictatorial way but in an atmosphere of love. When it comes to finance and major purchases, I make the decisions as I have the final say. With children, my wife has more freedom as she can deal with them better. Most of the time, I try to avoid unilateral decisions as much as possible but there might be situations when I have to make the decision but I see it as "authority used in the right way".

During an interview with Zena, she explained decision making in her household, such as their financial arrangements: "We make decisions together...we do it all together, we will always discuss and have a common decision. For example, although we both have a separate account, our incomes are joint because we do not consider our earnings as his or mine. I just withdraw the money from an account and hand the money to him and he will pay unless I am shopping alone."

Ben considers himself the main decision maker in the house, but Zena considered decision making to be shared. Further inconsistencies were detected in Zena's comments:

"We are not so individualistic that we have to decide what's his and what's mine. It is for the whole family... we earn together and I just have faith in Ben to make the decisions. Sometimes I do question his decisions...like do we really need to buy this item? But I tell myself to have faith in him and let him decide. This is how it should be...our religion has a big influence on all that we are doing... God created the hierarchy and everybody has their own role in the family. So, I respect my husband as the man of the house...I give him authority to make decisions and I am willing to be subordinated."

For Zena, even though she occasionally doubted her husband's decisions, she had to suppress her own feelings by telling herself to trust her husband because that was what her religion told her and, in accordance with her religion, it is legitimate. Therefore, we see patriarchal ideology (according to religious teachings) clashing with ideology of equality.

Like Zena, there were other Muslim female participants who reported how religious teachings affected the balance of power in their marital relationships. In a Muslim family, the husband is regarded as the head, a position that is sanctioned by religion (Yaacob Harun, 1996). The wife occupies a subordinate position and assumes the role of homemaker. Apart from managing household chores and taking care of the children, she also managed the family budget. This is illustrated 
in a Muslim couple, Aishah and Ahmad who has been married for 21 years and had six children. Aishah works as a cleaner and Ahmad works as a chef in a government psychiatric hospital. Their current organization of household income is that each have a separate bank account and according to Aishah, having a joint account meant no money for personal spending. Even with separate accounts, Aishah claims that her husband frequently asks for money from her and she constantly lied about a lack of money in order to give him less. She is unhappy but she does not dare to confront her husband directly and when I asked her why, she replied:

"I have to give in to him most of the time because my religion says that the husband is the man of the house, so he has the right to more power...if I have 100 Ringgit, I will say I have 50 only and I will further lie that is not my money and that I borrowed it from my friend. If he knew it was my money, he would never return it to me. I have learnt from my bad experiences with him that I cannot be too honest with my husband."

Ahmad on the other hand used legitimations to justify his behavior and manifest power such as threatening to divorce his wife if she disobeyed him:

"We do quarrel over money such that having enough money but I don't think it is a major problem. When we quarrel, my wife usually gives way...men are usually more ill-tempered so women should learn to give in. In Malay culture, men have more power... if she goes against me, it is disrespect and if she does it all the time, I will find someone else and divorce her."

\section{Discussion}

This research has examined the relationship between money, power and inequality among married couples in urban Sarawak based on the framework of resource theory. The findings of this research will be especially relevant for designing policies that enhances gender equality, and to empower all women and girls.

The first observation from this study is that measuring marital power through power outcomes such as control over economic resources and decision makings are inadequate and problematic as much of marital power is hidden or invisible. This is because there are situations where a resource like money conferring power may be active while at other times irrelevant. For example, the majority of couples in this study claimed that their household decision making process had nothing to do with income level. Only 11 out of 70 responses directly linked the power to control in household decisions with money and income level. Hence, contrary to the resource theory, the current study does not fully support the idea that money will bestow the owner with more marital power to make major decisions in the household.

The second observation made is that apart from money, marital power is affected by more influential factors such as ideologies and religious teachings. This is consistent with the findings of earlier researchers (Dempsy, 1997; Agarwal, 1997; Xu \& Lai, 2002). Consequently, having more money does not necessarily mean having more control over the decision-making process as decision making in a marriage is often guided by prescribed gender roles in accordance to one's ideologies, cultural and religious teachings. For example, the prominent ideology that emerged from this study include the male breadwinner ideology which regard man as the main provider for the family and hence will have a final say in the decision-making process in the household.

Based on the above discussion, the author postulates that having economic resources is not enough to achieve equality and balance of marital power in a marriage. What is more important is the willingness of the individuals to subscribe to and support non-traditional ideologies that bolster egalitarianism

\section{Conclusion}

This research endeavored to explore how married couples used money as a bargaining tool for more control in two areas: (1) managing economic resources and (2) household decision making. Using Sarawak as a case study, this research has revealed that having more money does not necessarily transcend to more marital power in decision making as decision making in a marriage is often guided by prescribed gender roles in accordance to one's ideologies, cultural and religious teachings. The significance influence of these factors and their impact on a marriage cannot be ignored. 
More importantly, this research demonstrates that having a source of income for married women is only the first step towards economic independence and equality in a marital relationship. If women want further improvements in both economic and sense of well-being, they need to work at bringing about more changes. In other words, women need to be more pro-active in initiating change to improve their well-being. Take housework, for example, where traditional gender roles have prescribed women to be mainly in charge of domestic work. If women want to unload some of these responsibilities, it would be important for her to bring the issue up for discussion and negotiation in her marriage as men generally will not be initiators as they are better off staying silent in these circumstances.

In addition, what is equally important is to bring about change in ideologies to further boost women's bargaining power in marriage. However, changing and controlling ideologies is no easy task and certainly beyond the capacity of an individual. This is because such changes require the involvement and the commitment of government and policy makers to change the country's policies in order to support changes in ideologies. For example, Kamal Malhorta, who was the United Nations resident coordinator in Malaysia ten years ago, pointed out that even though Malaysia has made progress in empowering women in education and work, our country still lags behind many developed countries in terms of gender equality. According to Malhorta, there is as much as a 20 per cent wage discrepancy between men and women in some professions. Also, women's participation in high-level decision making in the public and corporate sector is still fairly low (Hariati Azizan, 2011). A decade later, even though Malaysia has made notable progress on gender equality and women's economic empowerment, the gender gap in the Malaysia labour market still remains. For example, in accordance to the report published by United Nation Development Programme (2021), women in Malaysia are still earning an average annual income (RM37,248) that is less than the average income earned by men (RM39,648) in 2019. Moreover, women only occupy $24.7 \%$ of higher-level positions in the country while men occupied the remaining $75.3 \%$.

In sum, if we are serious about enhancing real gender equality in Malaysia, the government and policy makers will need to introduce more sustainable laws and regulations that address these equitable issues directly. This will include setting targets or quota to include women to hold leadership positions in both the public and private sectors and also to enforce a wage system that is fair and transparent in the country. Last but not least, creating awareness on gender equality can be achieved through education, mainstream and social media in order to bring about changes in the country's ideologies with regards to gender roles.

This research contributes to theory through its expansion of the extant of marital relationship literature on power and gender equality, as well as providing a deeper understanding of the role and influence of ideologies in a marriage. To the best of the author's knowledge, this research presents the only qualitative study that examines money and power among married couples of different ethnicities, and in Sarawak. 


\section{References}

Agarwal, B. (1997). Bargaining and gender relations: within and beyond the household. Feminist Economics, 3(1), 1-51.

Aminah Ahmad. (1995). Role conflict and coping behavior of married working women. Pertanika Journal of Social Science and Humanities, 3(2), 97-104.

Blood, R.O., \& Wolfe, D.M. (1960). Husbands and wives: the dynamics of married living, New York: Free Press.

Coltrane, S 2000, 'Research on household labour modelling and measuring the social embeddedness of routine family work', Journal of Marriage and Family, vol.62, no4, pp1208-1233.

Demsy, K. (1997). Inequalities in marriage: Australia and beyond, New Zealand: Oxford University Press.

Department of Statistics. (2020, February 23), Principle statistics of labour force, Malaysia, second quarter,2019, Retrieved from www.dosm.gov.my

Hariati Azizan. (2011, March 6). Still far from equal. The Star. http://mystarjob.com/articles/story.aspx?file=/2011/3/6/mystarjob_news/20110307111639\&sec=mystarjob_news

Komter, A. (1989). Hidden power in marriage. Gender and Society, 3(2), 187-216.

Noor Rahmah H.J. Abu Bakar. (1996). Working women and their families: a case study. Asian Profile. 24(2), 131-141.

Noraini M Noor. (1999). Roles and women's well-being: some preliminary findings from Malaysia. Sex Roles. 41, 123146.

Pyke, K.D. (1994). Women's employment as a gift or burden? Marital power across marriage, divorce, and remarriage. Gender and Society. 8(1), 77-91.

Rahmah, I., \& Fatimah, S. (1999). Women's education and household activities. In M. Ismail., and A. Ahmad (Eds), Women and work: challenges in industrializing nations (pp.27-56) London: Asean Academic Press.

Roziah, O. (2003). Negotiating their visibility: the lives of educated and married Malay women, Malaysia: Utasan Publisher.

Shove, E. (1993). Accounting for power: formal financial systems and domestic. In G. Dunne, R. Blackburn, \& J. Jarman (Eds), Inequalities in employment, inequalities in home life, Conference Proceedings for the $20^{\text {th }}$ Cambridge Stratification Seminar, University of Cambridge

Tichenor, V.J. (1999). Status and income as gendered resources: the case of marital power. Journal of Marriage and Family, 61(3), 638-650.

United Nation Development Programme. (2021). Issue Brief: Advancing gender equality in Malaysia (March 2021). United Nations Development Programme, Malaysia Country Office. https://www.my.undp.org/content/malaysia/en/home/library/womens_empowerment/issue-brief--advancing-genderequality-in-malaysia.html

West, C., \& Zimmerman, D.H. (1987). Doing gender. Gender and Society. 1(2),125-151.

Xu, X.H., \& Lai, S.C. (2002). Resources, gender ideologies and marital power: the case of Taiwan. Journal of Family Issues. 23(2), 209-245. 